\title{
Pengaruh Intensitas Modal, Financial Distress, Insentif Pajak dan Risiko Litigasi terhadap Konservatisme Akuntansi pada Perusahaan Manufaktur Sektor Industri Barang Konsumsi yang Terdaftar di Bursa Efek Indonesia Tahun 2016-2020
}

\author{
Ni Putu Dian Kristina Murti ${ }^{*}$, Gede Adi Yuniarta ${ }^{2}$ iD \\ ${ }^{13}$ Jurusan Ekonomi dan Akuntansi, Universitas Pendidikan Ganesha, Singaraja Bali, Indonesia \\ *niputudiankristinamurti01@undiksha.ac.id ${ }^{1 *}$
}

\begin{abstract}
Abstrak
Penelitian ini bertujuan untuk memperoleh hasil pengujian dari pengaruh (1) intensitas modal terhadap konservatisme akuntansi, (2) financial distress terhadap konservatisme akuntansi, (3) insentif pajak terhadap terhadap konservatisme akuntansi, dan (4) risiko litigasi terhadap konservatisme akuntansi. Jenis penelitian yang digunakan adalah penelitian kuantitatif. Populasi dalam penelitian ini adalah seluruh perusahaan manufaktur sektor industri barang konsumsi yang terdaftar di Bursa Efek Indonesia tahun 2016-2020 yang diketahui sebanyak 54 perusahaan dan teknik pengambilan sampel menggunakan metode purposive sampling. Diperoleh sampel sejumlah 23 perusahaan x 5 tahun $=115$ data laporan keuangan. Dalam penelitian ini, data yang digunakan adalah data sekunder dan teknik analisis yang digunakan yaitu metode analisis uji asumsi klasik, analisis regresi linier berganda, pengujian hipotesis dan koefisien determinasi. Hasil penelitian yang didapat dengan analisis regresi linier berganda disimpulkan bahwa intensitas modal, financial distress, insentif pajak dan risiko litigasi secara parsial berpengaruh signifikan terhadap konservatisme akuntansi pada perusahaan manufaktur sektor industri barang konsumsi yang terdaftar di Bursa Efek Indonesia tahun 2016-2020.
\end{abstract}

Kata Kunci : Intensitas Modal, Financial Distress, Insentif Pajak, Risiko Litigasi, dan Konservatisme Akuntansi.

\section{Abstract}

This study was aimed at finding out the effect of (1) capital intensity on accounting conservatism, (2) financial distress on accounting conservatism, (3) tax incentives on accounting conservatism, and (4) litigation risk on accounting conservatism. The type of research used is quantitative research. The population in this study are all manufacturing companies in the consumer goods industry sector listed on the Indonesia Stock Exchange in 2016-2020 which are known to be 54 companies and the sampling technique uses the purposive sampling method. Obtained a sample of 23 companies $x 5$ years $=115$ financial statement data. In this study, the data used are secondary data and the analytical techniques used are the classical assumption test analysis method, multiple linear regression analysis, hypothesis testing and the coefficient of determination. The results obtained using multiple linear regression analysis concluded that capital intensity, financial distress, tax incentives and litigation risk partially have a significant effect on accounting conservatism in manufacturing companies in the consumer goods industry sector listed on the Indonesia Stock Exchange in 2016-2020.

Keywords: Capital Intensity, Financial Distress, Tax Incentives, Litigation Risk, and Accounting Conservatism.

\section{Pendahuluan}

Seiring berkembangnya zaman yang semakin pesat mempengaruhi berbagai sektor kehidupan. Hal ini juga selaras dengan perkembangan usaha saat ini yang terus berkembang sehingga memicu persaingan yang ketat antar pelaku bisnis. Untuk dapat tetap eksis dan bertahan dalam persaingan yang ketat, setiap perusahaan harus melakukan yang terbaik untuk

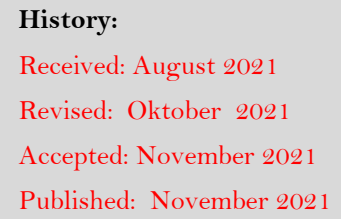


dilakukan dan ditampilkan kepada pihak internal maupun eksternal perusahaan. Salah satu sarana untuk menampilkan performa terbaik perusahaan yaitu dapat melalui laporan keuangan yang dapat mencerminkan kinerja keuangan perusahaan.

Standar Akuntansi Keuangan (SAK) memberikan kebebasan bagi manajemen dalam menentukan metode akuntansi konservatif yang digunakan dalam proses penyusunan laporan keuangan perusahaannya. Oleh karena itu dalam pembuatan laporan keuangan harus berdasarkan prinsip dasar laporan keuangan, salah satunya adalah prinsip kehati-hatian yang disebut dengan konservatisme. Dengan kebebasan yang dimiliki maka setiap metode yang dipilih oleh perusahaan memiliki tingkat konservatisme yang berbeda-beda pada setiap perusahaan. Dalam menghadapi suatu ketidakpastian di masa mendatang seorang manajer diharapkan menerapkan prinsip akuntansi konservatif.

Konservatisme sebagai prinsip akuntansi yang penerapannya dengan cara memperlambat mengakui laba atau pendapatan dan mempercepat mengakui biaya, sehingga apabila prinsip ini diterapkan maka akan menyebabkan angka laba dan pendapatan cenderung rendah sedangkan angka biaya cenderung tinggi (Noviantari, 2015).

Prinsip konservatisme akuntansi masih menuai pro dan kontra. Di satu sisi, konservatisme akuntansi konservatisme akuntansi maka laporan keuangan perusahaan yang diungkapkan akan bersifat bias dan tidak memperlihatkan keadaan atau kondisi perusahaan saat ini. Di sisi lain, konservatisme akuntansi dianggap baik untuk menghindari perilaku oportunistik manajer perusahaan yang berhubungan dengan dianggap sebagai kendala pada kualitas laporan keuangan, hal ini dikarenakan dengan adanya prinsip kontrak-kontrak yang menggunakan laporan keuangan.

Fenomena yang terjadi pada perusahan sektor industri barang konsumsi di Indonesia mengindikasikan rendahnya tingkat konservatisme akuntansi yang diterapkan perusahaan dalam menyusun laporan keuangannya. Hal ini dapat dilihat dari masih banyaknya perusahaan utamanya perusahaan manufaktur sektor industri barang konsumsi yang tidak menerapkan atau rendahnya tingkat konservatisme yang diterapkan perusahaan manufaktur sektor industri barang konsumsi pada tahun 2016 hingga 2020.

Salah satu kasus kecurangan tersebut terjadi pada tahun 2019 hingga 2020 yaitu pada PT Tiga Pilar Sejahtera Food Tbk. PT TPS Food merupakan perusahaan multinasional yang bergerak di bidang makanan ringan, salah satu produk andalan dan terkenal di kalangan masyarakat Indonesia yakni Taro. Pada laporan hasil investigasi Ernest \& Young pada bulan Maret 2019, PT TPS Food diduga melakukan penggelembungan dana pada laporan keuangan hingga Rp4.000.000.000.000,00 dugaan penggelembungan terjadi pada akun piutang usaha, aset tetap dan persediaan. Manajemen lama PT TPS Food juga diduga mengalirkan dana ke pihak terafiliasi sebesar Rp1.780.000.000.000,00. Tidak hanya melakukan penggelembungan mencapai Rp4.000.000.000.000,00 saja, tetapi juga melakukan penggelembungan dana sebesar Rp 662.000.000.000,00 pada akun pendapatan dan melakukan penggelembungan dana sebesar Rp 329.000.000.000,00 pada pos EBITDA (laba sebelum bunga, pajak, depresiasi dan amortisasi) di dalam laporan keuangannya. Selain temuan tersebut, Ernest \& Young juga menerangkan bahwa terdapat pencatatan data internal yang berbeda dengan pencatatan yang digunakan auditor keuangan dalam proses mengaudit laporan keuangan (Mayangsari, 2020).

Penerapan prinsip konservatisme di suatu perusahaan sendiri dipengaruhi oleh beberapa faktor, dan faktor yang digunakan sebagai variabel yang diteliti dalam penelitian ini adalah intensitas modal, financial distress, insentif pajak, dan risiko litigasi.

Berdasarkan latar belakang yang telah diuraikan diatas, dan penelitian-penelitian terdahulu dengan hasil penelitian yang tidak konsisten maka peneliti tertarik untuk melakukan penelitian yang serupa dengan menggunakan konservatisme akuntansi sebagai 
variabel dependen, dan empat variabel independent lainnya yaitu Intensitas Modal, Financial Distress, Insentif Pajak, dan Risiko Litigasi. Maka dari itu peneliti melakukan penelitian dengan judul "Pengaruh Intensitas Modal, Financial Distress, Insentif Pajak dan Risiko Litigasi terhadap Konservatisme Akuntansi Pada Perusahaan Manufaktur Sektor Industri Barang Konsumsi yang Terdaftar di Bursa Efek Indonesia Tahun 2016-2020”.

Penelitian ini menggunakan teori yang relevan yaitu teori keagenan. Teori tersebut memegang peran penting dalam praktik bisnis perusahaan. Menurut Jensen dan Meckling (1976) bahwa konsep agency theory merupakan hubungan keagenan sebagai suatu kontrak yang mana satu atau lebih prinsipal (pemegang saham) menggunakan pihak lain atau agen (manajer) untuk menjalankan aktivitas perusahaan.

Selain teori keagenan, penelitian ini juga didasari oleh teori sinyal (signaling theory). Teori sinyal ini menekankan adanya informasi yang dikeluarkan oleh perusahaan terhadap keputusan investasi yang ditujukan kepada pihak luar perusahaan termasuk para investor dan pemangku kepentingan lainnya untuk menunjukkan bahwasannya perusahaan tersebut lebih baik dari perusahaan lain.

\section{Pengaruh Intensitas Modal terhadap Konservatisme Akuntansi}

Intensitas modal merupakan gambaran dari besaran modal yang dibutuhkan perusahaan untuk memperoleh pendapatan. Perusahaan yang padat modal berhadapan dengan biaya politik yang relatif lebih besar, sehingga manajemen cenderung berhati-hati dan akan memilih prosedur akuntansi yang tidak melebih-lebihkan laba, dengan demikian laporan keuangan yang dihasilkan bersifat konservatif (Rivandi, 2018).

Sinambela, M. O. E., \& Almilia, L. S. (2018) menunjukkan bahwa intensitas modal berpengaruh negatif terhadap konservatisme akuntansi. Berbeda halnya dengan penelitian yang dilakukan oleh Alfian \& Sabeni (2013) dan Susanto \& Ramadhani (2016) yang menyatakan bahwa intensitas modal berpengaruh positif dan signifikan terhadap konservatisme akuntansi. Berdasarkan teori dan hasil penelitian maka dapat diturunkan hipotesis yang akan dibuktikan secara empiris:

$\mathrm{H}_{1}$ : Intensitas modal berpengaruh terhadap konservatisme akuntansi.

\section{Pengaruh Financial Distress terhadap Konservatisme Akuntansi}

Tingkat kesulitan keuangan bisa diartikan sebagai munculnya sinyal atau gejala- gejala awal kebangkrutan terhadap penurunan kondisi keuangan yang dialami suatu perusahaan, atau kondisi sebelum terjadi kebangkrutan atau likuidasi. Ketika perusahaan mengalami financial distress maka harga saham perusahaan menurun serta berkurangnya investor pada perusahaan. Tingkat kesulitan keuangan ini membantu dalam penerapan prinsip lebih konservatif akibat pengakuan laba yang tidak berlebihan atau mengakui laba yang lebih rendah untuk pengakuan laba di masa depan dengan bertujuan untuk mencegah kesulitan keuangan perusahaan. Hasil penelitian yang dilakukan Dewi dan Suryanawa (2014) menunjukkan bahwa financial distress berpengaruh signifikan positif terhadap konservatisme akuntansi. Risdiyani, F., \& Kusmuriyanto, K. (2015) menunjukkan bahwa financial distress berpengaruh negatif terhadap konservatisme akuntansi. Yuniarti, N (2020) menunjukkan financial distress berpengaruh terhadap konservatisme akuntansi. Berdasarkan teori dan hasil penelitian maka dapat diturunkan hipotesis yang akan dibuktikan secara empiris:

$\mathrm{H}_{2}$ : Financial distress berpengaruh terhadap konservatisme akuntansi.

\section{Pengaruh Insentif Pajak terhadap Konservatisme Akuntansi}

Rahmawati (2017) menyebutkan semakin besar perusahaan maka semakin besar perhatian pemerintah terhadap perusahaan tersebut dan semakin besar kemungkinan untuk 
diatur. Penelitian ini memprediksi bahwa perusahaan dengan pajak semakin besar maka cenderung memilih akuntansi yang lebih konservatif. Menurut penelitian Sugiyarti, L., \& Rina, S. (2020) menunjukan bahwa insentif pajak berpengaruh terhadap konservatisme akuntansi. Berdasarkan teori dan hasil penelitian maka dapat diturunkan hipotesis yang akan dibuktikan secara empiris:

\section{$H_{3}$ : Insentif pajak berpengaruh terhadap konservatisme akuntansi.}

\section{Pengaruh Risiko Litigasi terhadap Konservatisme Akuntansi}

Risiko litigasi yang dalam hal ini sebagai faktor eksternal dapat mendorong manajer untuk laporan keuangan perusahaan lebih konservatif. Bila resiko ancaman litigasi pada perusahaan relatif tinggi dorongan manajer untuk menerapkan prinsip konservatisme akuntansi akan semakin kuat (Ramadhoni, 2014). Berdasarkan penelitian yang dilakukan oleh Saputra (2016) menunjukkan bahwa risiko litigasi memiliki pengaruh signifikan terhadap konservatisme akuntansi. Hal ini tidak sejalan dengan penelitian Yuniarti, N (2020) yang menunjukkan risiko litigasi tidak berpengaruh terhadap konservatisme akuntansi. Berdasarkan teori dan hasil penelitian maka dapat diturunkan hipotesis yang akan dibuktikan secara empiris:

$\mathrm{H}_{4}$ : Risiko Litigasi berpengaruh terhadap konservatisme akuntansi.

\section{Metode}

Penelitian ini menggunakan metode kuantitatif. Data yang digunakan dalam penelitian ini adalah data sekunder berupa laporan tahunan perusahaan dan juga data lainnya yang dapat mendukung penelitian ini. Populasi dalam penelitian ini adalah perusahaan-perusahaan manufaktur sektor industri barang konsumsi yang terdaftar di Bursa Efek Indonesia yaitu sebanyak 54 perusahaan selama periode penelitian 2016 sampai 2020. Adapun kriteria sampel yaitu:1.Perusahaan manufaktur sektor industri barang konsumsi yang terdaftar di Bursa Efek Indonesia (BEI) selama periode 2016-2020, 2. Perusahaan manufaktur sektor industri barang konsumsi yang telah mempublikasikan dan menyajikan data laporan keuangan tahunan secara lengkap selama periode 2016-2020, 3. Menyajikan laporan keuangan dalam satuan mata uang rupiah penuh dalam laporan keuangannya, 4. Perusahaan memperoleh laba secara berturut-turut selama periode 2016-2020.

Dari 54 perusahaan yang masih listing di Bursa Efek Indonesia, terdapat 23 perusahaan yang memenuhi kriteria yang telah ditetapkan untuk dijadikan sampel penelitian.

Metode pengumpulan data yang digunakan adalah metode purposive sampling. Dengan metode tersebut sampel dipilih berdasarkan kriteria tertentu yang sesuai dengan kebutuhan penelitian.

Pada penelitian ini data diolah menggunakan program SPSS 24.0 for windows. Adapun teknik analisis data yang digunakan dalam penelitian ini adalah analisis statistik deskriptif, uji asumsi klasik yang terdiri dari uji normalitas, uji multikolinearitas, uji heteroskedastisitas dan uji autokorelasi. Kemudian Uji hipotesis terdiri dari Analisis Regresi Linear Berganda, Uji t, koefisien determinasi (R2).

\section{Hasil dan Pembahasan}

Hasil Analisis Statistik Deskriptif

Hasil dari analisis statistik deskriptif dapat dilihat pada tabel di bawah ini: 
Tabel 1. Hasil Analisis Deskriptif

\begin{tabular}{cllll}
\hline Variabel & \multicolumn{1}{c}{ Minimum } & \multicolumn{1}{c}{ Maksimum } & \multicolumn{1}{c}{ Rata-rata } & \multicolumn{1}{c}{ Standar Deviasi } \\
\hline $\mathrm{X}_{1}$ & 0,322 & 2,243 & 1,027 & 0,438 \\
\hline $\mathrm{X}_{2}$ & $-0,469$ & 64,090 & 5,199 & 8,566 \\
\hline $\mathrm{X}_{3}$ & $-0,002$ & 0,216 & 0,033 & 0,032 \\
\hline $\mathrm{X}_{4}$ & 27,058 & 33,797 & 30,038 & 1,639 \\
\hline $\mathrm{Y}(\mathrm{Rp})$ & -4364093000000 & 7431859000000 & $-205986485238,97$ & 1309976699295,76 \\
\hline
\end{tabular}

Sumber: Diolah Peneliti, 2021

Berdasarkan data pada tabel 1 dapat diketahui nilai maksimum, minimum, nilai ratarata serta standar deviasi yang ada pada masing-masing variabel.

\section{Hasil Uji Asumsi Klasik}

Uji asumsi klasik terhadap model regresi yang digunakan dalam penelitian, dilakukan untuk menguji apakah model regresi tersebut baik atau tidak. Dalam penelitian ini, uji asumsi klasik yang digunakan adalah uji normalitas, uji multikolinearitas, uji heterokedastisitas dan uji autokorelasi.

Tabel 2.Hasil Uji Normalitas Data

\begin{tabular}{lr}
\hline \multicolumn{2}{c}{ One-Sample Kolmogorov-Smirnov Test } \\
\hline $\mathrm{N}$ & Unstandardized Residual \\
\hline Kolmogorov-Smirnov $Z$ & 115 \\
\hline Asymp. Sig. (2-tailed) & 0,078 \\
\hline Sumber: Diof Pen & 0,081 \\
\hline
\end{tabular}

Sumber: Diolah Peneliti, 2021

Berdasarkan tabel 2 terlihat bahwa nilai asymptotic significance yang dperoleh pada uji Kolmogorov-Smirnov sebesar 0,081 di atas tingkat signifikan 0,05 (5\%) maka dapat diartikan bahwa nilai residual terdistribusi normal, dengan demikian persamaan regresi yang diperoleh memenuhi asumsi normalitas dan dapat digunakan untuk pengambilan keputusan.

Tabel 3. Hasil Uji Multikolinieritas

\begin{tabular}{cccc}
\hline \multirow{2}{*}{ Model } & \multicolumn{2}{c}{ Collinearity Statistics } & \multirow{2}{*}{ Keterangan } \\
\cline { 2 - 3 } & Tolerance & VIF & \\
\hline $\mathrm{X}_{1}$ & 0,707 & 1,414 & Tidak ada multikolinieritas \\
\hline $\mathrm{X}_{2}$ & 0,654 & 1,530 & Tidak ada multikolinieritas \\
\hline $\mathrm{X}_{3}$ & 0,674 & 1,485 & Tidak ada multikolinieritas \\
\hline $\mathrm{X}_{4}$ & 0,688 & 1,453 & Tidak ada multikolinieritas \\
\hline
\end{tabular}

Sumber: Diolah Peneliti, 2021

Berdasarkan Tabel 3 diketahui bahwa nilai VIF dari masing-masing variabel bebas lebih kecil dari 10 dan nilai tolerance lebih dari 0,10. Dengan demikian hasil tersebut tidak melebihi batas nilai Tolerance dan VIF yang diperkenankan. Nilai korelasi di antara variabel bebas dapat dikatakan mempunyai korelasi yang lemah. Dengan demikian dapat disimpulkan bahwa model regresi yang dihasilkan tidak terjadi multikolinearitas.

Tabel 4. Hasil Uji Heteroskedastisitas

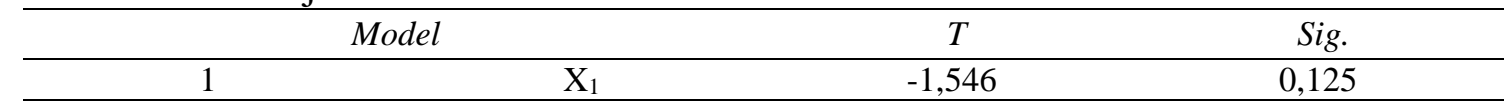




\begin{tabular}{llll}
\hline & $\mathrm{X}_{2}$ & 1,912 & 0,058 \\
\cline { 2 - 4 } & $\mathrm{X}_{3}$ & 0,810 & 0,420 \\
\cline { 2 - 4 } & $\mathrm{X}_{4}$ & $-0,384$ & 0,702 \\
\hline
\end{tabular}

a. Dependent Variable: ABS

Sumber: Diolah Peneliti, 2021

Berdasarkan Tabel 4 diketahui bahwa nilai signifikansi antara variabel bebas dengan absolute residual (ABS) lebih besar dari 0,05. Jadi, dapat disimpulkan bahwa model regresi yang digunakan tidak terdapat adanya gejala heteroskedastisitas.

Tabel 5. Hasil Uji Autokorelasi

\begin{tabular}{ccccc}
\hline Model & $\mathrm{R}$ & $\mathrm{R}$ Square & Adjusted $\mathrm{R}$ Square & Durbin Watson \\
\hline 1 & 0,800 & 0,640 & 0,627 & 2,079 \\
\hline
\end{tabular}

Sumber: Diolah Peneliti, 2021

Berdasarkan Tabel 5 diketahui bahwa nilai Durbin Watson sebesar 2,079. Nilai tabel Durbin Watson pada $\alpha=0,05, \mathrm{n}=115, \mathrm{k}=4$ adalah $\mathrm{dU}=1,768$. Nilai Durbin Watson berada di antara dU dan $(4-\mathrm{dU})$ atau 1,768<2,079<2,232. Dengan demikian, dapat disimpulkan bahwa dalam regresi linier tidak ada autokorelasi.

Analisis regresi dalam penelitian ini menggunakan analisis regresi linier berganda yang bertujuan untuk menguji pengaruh variabel independent (intensitas modal, financial distress, insentif pajak,risiko litigasi) terhadap variabel dependen (konservatisme akuntansi). Hasil perhitungan regresi linier berganda dapat dilihat pada tabel berikut ini:

Tabel 6. Hasil Analisis Koefisien Beta dan Uji t

\begin{tabular}{|c|c|c|c|c|c|}
\hline \multirow{2}{*}{\multicolumn{2}{|c|}{ Model }} & $\begin{array}{c}\text { Unstandardized } \\
\text { Coefficients }\end{array}$ & $\begin{array}{c}\text { Standardized } \\
\text { Coefficients }\end{array}$ & $t$ & Sig. \\
\hline & & $B$ & Beta & & \\
\hline \multirow[t]{5}{*}{1} & (Constant) & -7680176359000 & & $-4,937$ & 0,000 \\
\hline & $\mathrm{X}_{1}$ & 847004031400 & 0,283 & 4,163 & 0,000 \\
\hline & $\mathrm{X}_{2}$ & 56445819490 & 0,369 & 5,214 & 0,000 \\
\hline & $\mathrm{X}_{3}$ & 7508610509000 & 0,181 & 2,600 & 0,011 \\
\hline & $\mathrm{X}_{4}$ & 201872618300 & 0,253 & 3,661 & 0,000 \\
\hline
\end{tabular}

a. Dependent Variable: $\mathrm{Y}$

Sumber: Diolah Peneliti, 2021

Berdasarkan perhitungan regresi linier berganda pada Tabel 6, maka didapat hasil persamaan regresi sebagai berikut.

$\mathrm{Y}=\alpha+\beta 1 \mathrm{X} 1+\beta 2 \mathrm{X} 2+\beta 3 \mathrm{X} 3+\beta 4 \mathrm{X} 4+\varepsilon$

$\mathrm{Y}=-7680176359000+0,283 \mathrm{X} 1+0,369 \mathrm{X} 2+0,181 \mathrm{X} 3+0,253 \mathrm{X} 4+\varepsilon$

Berdasarkan model regresi yang terbentuk, dapat diinterpretasikan hasil sebagai berikut.

1. Konstanta -7680176359000 menunjukan jika variabel intensitas modal (X1), financial distress (X2), insentif pajak (X3), dan risiko litigasi (X4) bernilai konstan, maka variabel konservatisme akuntansi (Y) memiliki nilai -7680176359000.

2. Intensitas modal (X1) memiliki koefisien regresi 0,283. Nilai koefisien regresi yang positif menunjukkan bahwa intensitas modal (X1) berpengaruh positif terhadap konservatisme akuntansi (Y). 
3. Financial distress (X2) memiliki koefisien regresi 0,369. Nilai koefisien regresi yang positif menunjukkan bahwa financial distress (X2) berpengaruh positif terhadap konservatisme akuntansi (Y).

4. Insentif pajak (X3) memiliki koefisien regresi 0,181. Nilai koefisien regresi yang positif menunjukkan bahwa insentif pajak (X3) berpengaruh positif terhadap konservatisme akuntansi (Y).

5. Risiko litigasi (X4) memiliki koefisien regresi 0,253. Nilai koefisien regresi yang positif menunjukkan bahwa risiko litigasi (X4) berpengaruh positif terhadap konservatisme akuntansi (Y).

Tabel 7. Hasil Koefisien Determinasi

\begin{tabular}{cccc}
\hline Model & $\mathrm{R}$ & $\mathrm{R}$ Square & $\begin{array}{c}\text { Adjusted } \\
\mathrm{R} \text { Square }\end{array}$ \\
\hline 1 & 0,800 & 0,640 & 0,627 \\
\hline
\end{tabular}

Sumber: Diolah Peneliti, 2021

Berdasarkan Tabel 7, diketahui bahwa koefisien determinasi sebesar 0,627. Hal ini menunjukkan bahwa $62,7 \%$ variabel konservatisme akuntansi dipengaruhi oleh variabel intensitas modal, financial distress, insentif pajak, dan risiko litigasi, sedangkan 37,3\% dipengaruhi oleh faktor lain.

Setelah uji regresi linier berganda dan uji koefisien determinasi (R2) dilakukan, maka dilanjutkan dengan menggunakan uji t. Uji t digunakan untuk menentukan analisis pengaruh intensitas modal, financial distress, insentif pajak, dan risiko litigasi terhadap konservatisme akuntansi secara parsial, dimana dapat dilihat dari besarnya nilai probabilitas pada uji t. Adapun penerimaan hipotesis dilakukan dengan kriteria, apabila nilai signifikansi t statistik < 0,05, maka H0 ditolak, artinya suatu variabel independen secara individual berpengaruh terhadap variabel dependen. Sesuai dengan hipotesis yang diajukan dalam penelitian ini, maka berdasarkan tabel 6 hasil pengujian hipotesis sebagai berikut.

1.Uji Hipotesis 1

Perumusan hipotesis:

$\mathrm{H0}$ : intensitas modal tidak berpengaruh terhadap konservatisme akuntansi.

H1: intensitas modal berpengaruh terhadap konservatisme akuntansi.

Hasil pengujian hipotesis pertama menunjukkan bahwa intensitas modal memiliki nilai signifikansi uji t sebesar 0,000, dimana nilai tersebut lebih kecil dari 0,05 sehingga H1 diterima. Jadi, dapat disimpulkan bahwa intensitas modal berpengaruh terhadap konservatisme akuntansi.

2.Uji Hipotesis 2

Perumusan hipotesis:

H0: financial distress tidak berpengaruh terhadap konservatisme akuntansi.

$\mathrm{H} 2$ : financial distress berpengaruh terhadap konservatisme akuntansi.

Hasil pengujian hipotesis kedua menunjukkan bahwa financial distress memiliki nilai signifikansi uji t sebesar 0,000, dimana nilai tersebut lebih kecil dari 0,05 sehingga $\mathrm{H} 2$ diterima. Jadi, dapat disimpulkan bahwa financial distress berpengaruh terhadap konservatisme akuntansi.

3. Uji Hipotesis 3

Perumusan hipotesis:

H0: insentif pajak tidak berpengaruh terhadap konservatisme akuntansi.

H3: insentif pajak berpengaruh terhadap konservatisme akuntansi. 
Hasil pengujian hipotesis ketiga menunjukkan bahwa insentif pajak memiliki nilai signifikansi uji t sebesar 0,011, dimana nilai tersebut lebih kecil dari 0,05 sehingga H3 diterima. Jadi, dapat disimpulkan bahwa insentif pajak berpengaruh terhadap konservatisme akuntansi.

4. Uji Hipotesis 4

Perumusan hipotesis:

H0: risiko litigasi tidak berpengaruh terhadap konservatisme akuntansi.

H4: risiko litigasi berpengaruh terhadap konservatisme akuntansi.

Hasil pengujian hipotesis keempat menunjukkan bahwa risiko litigasi memiliki nilai signifikansi uji t sebesar 0,000, dimana nilai tersebut lebih kecil dari 0,05 sehingga H4 diterima. Jadi, dapat disimpulkan bahwa risiko litigasi berpengaruh terhadap konservatisme akuntansi.

\section{Pengaruh Intensitas Modal terhadap Konservatisme Akuntansi}

Berdasarkan hasil uji regresi linier berganda didapatkan bahwa koefisien regresi intensitas modal sebesar 0,283 yang berarti bahwa apabila terdapat penambahan intensitas modal sebesar 1 satuan, maka konservatisme akuntansi akan meningkatkan sebesar 0,283 satuan dengan asumsi variabel lain bernilai tetap. Hasil tersebut menunjukkan bahwa variabel intensitas modal berpengaruh positif terhadap konservatisme akuntansi.

Hasil uji statistik t menunjukkan bahwa variabel intensitas modal mempunyai nilai signifikansi sebesar 0,000. Nilai signifikansi untuk variabel intensitas modal lebih kecil daripada nilai probabilitas $\alpha=0,05$. Hal tersebut menunjukkan bahwa variabel intensitas modal berpengaruh signifikan terhadap konservatisme akuntansi. Dengan demikian hipotesis pertama (H1), yaitu intensitas modal berpengaruh terhadap konservatisme akuntansi dapat diterima. Jadi hasil penelitian ini mengindikasikan bahwa setiap peningkatan atau penurunan intensitas modal selama periode penelitian yaitu dari tahun 2016-2020 mempunyai pengaruh terhadap konservatisme akuntansi.

Hasil penelitian ini didukung oleh teori keagenan menurut Jensen dan Meckling (1976) bahwa konsep teori agensi atau agency theory merupakan hubungan keagenan sebagai suatu kontrak yang mana satu atau lebih prinsipal (pemegang saham) menggunakan pihak lain atau agen (manajer) untuk menjalankan aktifitas perusahaan. Dalam penelitian ini manajer perusahaan (agen) berupaya menyajikan laporan keuangan yang konservatif untuk menghindari timbulnya biaya politis yang besar. Perusahaan yang besar merupakan perusahaan yang padat modal dan lebih menimbulkan adanya biaya-biaya politis. Pemerintah cenderung mengalokasikan biaya politis yang besar pada perusahaan yang padat modal. Maka perusahaan dengan keadaan yang padat modal akan melakukan pelaporan secara konservatif.

Kajian emperik yang turut mendukung temuan penelitian ini adalah hasil penelitian yang dilakukan oleh penelitian Alfian \& Sabeni (2013) dan Susanto \& Ramadhani (2016) yang menyatakan bahwa intensitas modal berpengaruh positif dan signifikan terhadap konservatisme akuntansi.

Pengaruh Financial Distress terhadap Konservatisme Akuntansi

Berdasarkan hasil uji regresi linier berganda didapatkan bahwa koefisien regresi financial distress sebesar 0,369 yang berarti bahwa apabila terdapat penambahan financial distress sebesar 1 satuan, maka konservatisme akuntansi akan meningkatkan sebesar 0,369 satuan dengan asumsi variabel lain bernilai tetap. Hasil tersebut menunjukkan bahwa variabel financial distress berpengaruh positif terhadap konservatisme akuntansi.

Hasil uji statistik $\mathrm{t}$ menunjukkan bahwa variabel financial distress mempunyai nilai signifikansi sebesar 0,000. Nilai signifikansi untuk variabel financial distress lebih kecil 
daripada nilai probabilitas $\alpha=0,05$. Hal tersebut menunjukkan bahwa variabel financial distress berpengaruh signifikan terhadap konservatisme akuntansi. Dengan demikian hipotesis kedua (H2), yaitu financial distress berpengaruh terhadap konservatisme akuntansi dapat diterima. Jadi hasil penelitian ini mengindikasikan bahwa setiap peningkatan atau penurunan financial distress selama periode penelitian yaitu dari tahun 2016-2020 mempunyai pengaruh terhadap konservatisme akuntansi.

Hasil penelitian ini didukung oleh teori signaling yang menjelaskan bahwa pemberian sinyal dilakukan oleh manajer untuk mengurangi asimetri informasi. Manajer memberikan informasi melalui laporan keuangan bahwa mereka menerapkan kebijakan akuntansi konservatisme yang menghasilkan laba lebih berkualitas karena prinsip ini mencegah perusahaan melakukan tindakan membesar-besarkan laba dan membantu pengguna laporan keuangan dengan menyajikan laba dan aktiva yang tidak overstate (Fala dan Nugroho, 2012).

Kajian emperik yang turut mendukung temuan penelitian ini adalah hasil penelitian yang dilakukan oleh Suryadani dan Priyanto (2012) dan Sulastri, S., \& Anna, Y. D. (2018) yang menyatakan bahwa financial distress berpengaruh positif dan signifikan terhadap konservatisme akuntansi.

\section{Pengaruh Insentif Pajak terhadap Konservatisme Akuntansi}

Berdasarkan hasil uji regresi linier berganda didapatkan bahwa koefisien regresi insentif pajak sebesar 0,181 yang berarti bahwa apabila terdapat penambahan insentif pajak sebesar 1 satuan, maka konservatisme akuntansi akan meningkatkan sebesar 0,181 satuan dengan asumsi variabel lain bernilai tetap. Hasil tersebut menunjukkan bahwa variabel insentif pajak berpengaruh positif terhadap konservatisme akuntansi.

Hasil uji statistik t menunjukkan bahwa variabel insentif pajak mempunyai nilai signifikansi sebesar 0,011. Nilai signifikansi untuk variabel insentif pajak lebih kecil daripada nilai probabilitas $\alpha=0,05$. Hal tersebut menunjukkan bahwa variabel insentif pajak berpengaruh signifikan terhadap konservatisme akuntansi. Dengan demikian hipotesis ketiga (H3), yaitu insentif pajak berpengaruh terhadap konservatisme akuntansi dapat diterima. Jadi hasil penelitian ini mengindikasikan bahwa setiap peningkatan atau penurunan insentif pajak selama periode penelitian yaitu dari tahun 2016-2020 mempunyai pengaruh terhadap konservatisme akuntansi.

Hasil penelitian ini didukung oleh teori keagenan menurut Jensen dan Meckling (1976) bahwa konsep teori agensi atau agency theory merupakan hubungan keagenan sebagai suatu kontrak yang mana satu atau lebih prinsipal (pemegang saham) menggunakan pihak lain atau agen (manajer) untuk menjalankan aktifitas perusahaan. Dalam penelitian ini manajer perusahaan berupaya memaksimalkan nilai perusahaan dengan meminimalkan beban pajak melalui penerapan prinsip konservatisme akuntansi saat penyusunan laporan keuangan untuk dapat menerima pengurangan tarif pajak yang diberlakukan pemerintah.

Kajian emperik yang turut mendukung temuan penelitian ini adalah hasil penelitian yang dilakukan oleh Sugiyarti, L., \& Rina, S. (2020) menunjukan bahwa insentif pajak berpengaruh terhadap konservatisme akuntansi.

\section{Pengaruh Risiko Litigasi terhadap Konservatisme Akuntansi}

Berdasarkan hasil uji regresi linier berganda didapatkan bahwa koefisien regresi risiko litigasi sebesar 0,253 yang berarti bahwa apabila terdapat penambahan risiko litigasi sebesar 1 satuan, maka konservatisme akuntansi akan meningkatkan sebesar 0,253 satuan dengan asumsi variabel lain bernilai tetap. Hasil tersebut menunjukkan bahwa variabel risiko litigasi berpengaruh positif terhadap konservatisme akuntansi. 
Hasil uji statistik t menunjukkan bahwa variabel risiko litigasi (X1) mempunyai nilai signifikansi sebesar 0,000. Nilai signifikansi untuk variabel risiko litigasi (X1) lebih kecil daripada nilai probabilitas $\alpha=0,05$. Hal tersebut menunjukkan bahwa variabel risiko litigasi berpengaruh signifikan terhadap konservatisme akuntansi. Dengan demikian hipotesis keempat (H4), yaitu risiko litigasi berpengaruh terhadap konservatisme akuntansi dapat diterima. Jadi hasil penelitian ini mengindikasikan bahwa setiap peningkatan atau penurunan risiko litigasi selama periode penelitian yaitu dari tahun 2016-2020 mempunyai pengaruh terhadap konservatisme akuntansi.

Hasil penelitian ini didukung oleh teori keagenan, teori keagenan kaitannya dengan risiko litigasi yaitu risiko litigasi sebagai faktor ekternal dapat mendorong manajer untuk melaporkan keuangan perusahaan lebih konservatif. Dorongan manajer untuk menerapkan konservatisme akuntansi akan semakin kuat bila risiko ancaman litigasi pada perusahaan relatif tinggi (Cao dan Narayanamoorthy 2005). Risiko litigasi merupakan risiko yang berpotensi menimbulkan biaya yang tidak sedikit karena berurusan dengan masalah hukum. Secara rasional manajer akan menghindari kerugian akibat litigasi tersebut dengan cara melaporkan keuangan secara konservatif, karena laba yang terlalu tinggi memiliki potensi risiko litigasi lebih tinggi (Juanda, 2007).

Kajian emperik yang turut mendukung temuan penelitian ini adalah hasil penelitian yang dilakukan oleh Ramadhoni (2014) dan Saputra (2016) menunjukkan bahwa risiko litigasi berpengaruh positif dan signifikan terhadap konservatisme akuntansi.

\section{Simpulan dan Saran}

Berdasarkan hasil penelitian dan pembahasan, maka diperoleh simpulan yaitu 1) Intensitas modal secara parsial berpengaruh terhadap konservatisme akuntansi pada Perusahaan Manufaktur Sektor Industri Barang Konsumsi yang terdaftar di Bursa Efek Indonesia (BEI) tahun 2016-2020, 2) Financial distress secara parsial berpengaruh terhadap konservatisme akuntansi pada Perusahaan Manufaktur Sektor Industri Barang Konsumsi yang terdaftar di Bursa Efek Indonesia (BEI) tahun 2016-2020, 3) Insentif pajak secara parsial berpengaruh terhadap konservatisme akuntansi pada Perusahaan Manufaktur Sektor Industri Barang Konsumsi yang terdaftar di Bursa Efek Indonesia (BEI) tahun 2016-2020, 4) Risiko litigasi secara parsial berpengaruh terhadap konservatisme akuntansi pada Perusahaan Manufaktur Sektor Industri Barang Konsumsi yang terdaftar di Bursa Efek Indonesia (BEI) tahun 2016-2020.

Berdasarkan hasil pembahasan dan simpulan yang diperoleh dalam penelitian ini, maka saran yang dapat diberikan yaitu 1) Bagi perusahaan, prinsip konservatisme akuntansi masih dianggap prinsip kontroversial di kalangan peneliti, oleh karena itu disarankan kepada perusahaan agar lebih bijak dan cermat dalam menerapkan konservatisme akuntansi agar tidak melanggar ketentuan hukum dan tidak menyimpang dari standar akuntansi yang berlaku, 2) Investor, calon investor dan kreditur disarankan untuk lebih berhati-hati atas informasi yang disajikan pada laporan keuangan, dan mampu menyimak laporan keuangan tahunan yang dipublikasikan di Bursa Efek Indonesia agar mampu mengetahui kualitas laba perusahaan di dalam pengambilan keputusan, 3) Diharapkan penelitian selanjutnya dapat menggunakan sampel dari sektor lainnya seperti perusahaan real estate, pertambangan, perbankan atau dengan memperluas objek penelitian dengan menggunakan seluruh perusahaan yang terdaftar di Bursa Efek Indonesia (BEI).

Penelitian ini hanya menggunakan tahun pengamatan selama 5 periode, diharapkan untuk penelitian selanjutnya dapat menambah tahun periode pengamatan untuk memperoleh prediksi yang lebih efisien selain itu diharapkan untuk penelitian selanjutnya dapat 
menambah variabel penelitian lain seperti growth opportunity, debt covenant, kepemilikan instutisional, ukuran perusahaan, bonus plan, ceo retirement, dan sebagainya.

\section{Daftar Pustaka}

Alfian, A., \& Sabeni, A. (2013). Analisis Faktor-Faktor Yang Berpengaruh Terhadap Pemilihan Konservatisme Akuntansi. Diponegoro Journal Of Accounting, 2(3), 1-10. https://ejournal3.undip.ac.id/index.php/accounting/article/view/3386/3318

Dewi, N. K. S. L., \& Suryanawa, I. K. (2014). Pengaruh struktur kepemilikan manajerial, leverage, dan financial distress terhadap konservatisme akuntansi. E-Jurnal Akuntansi, $7(1), 223-234$.

Ghozali, Imam. 2011. Aplikasi Analisis Multivariate dengan Program IBM SPSS 25. Semarang: Badan Penerbit Universitas Diponegoro.

Jensen, M. C., Dan Meckling W. H. 1976. "Theory of The Firm: Managerial Behaviour, Agency Cost, and Ownership Structure". Journal of Financial Economics. 3 (1976) 305360.

Juanda, Ahmad. 2007. "Pengaruh Risisko Litigasi dan Tipe Strategi terhadap Hubungan Antara Konflik Kepentingan dan Konservatisme Akuntansi". Simposium Nasional Akuntansi X. Makasar.

Mayangsari, T. 2020. Penerapan Beneish M-Score Model Dan Altman Z-Score Model Dalam Pendeteksian Kecurangan Pelaporan Keuangan (Studi Kasus PT Tiga Pilar Sejahtera Food Tbk) (Doctoral dissertation, Universitas Muhammadiyah Malang).

Narayanamoorthy, G., \& Cao, Z. (2005). The effect of litigation risk on management earnings forecasts. Working Paper, Yale University.

Noviantari, Ni Wayan dan Ni Made Dwi Ratnadi. 2015. "Pengaruh Financial Distress, Ukuran Perusahaan, dan Leverage pada Konservatisme Akuntansi”. Jurnal Akuntansi Universitas Udayana. Vol. 11, No. 3, hal: 646-660. https://ocs.unud.ac.id/index.php/Akuntansi/article/view/12646

Nugroho, D. A., \& SITI, M. (2012). Pengaruh Struktur Kepemilikan Manajerial, Debt Covenant, Tingkat Kesulitan Keuangan Perusahaan, dan Risiko Litigasi terhadap Konservatisme Akuntansi (Studi Empiris pada Perusahaan Manufaktur yang terdaftar di BEI Tahun 2008-2010) (Doctoral dissertation, Fakultas Ekonomika dan Bisnis).

Ramadhoni, Yogie. 2014. "Pengaruh Tingkat Kesulitan Keuangan Perusahaan, Risiko Litigasi, Struktur Kepemilikan Manajerial, dan Debt Covenant Terhadap Konservatisme Akuntansi”. JOM Fekon. Vol. 1, No. 2, Oktober 2014 hal: 1- 20. https://media.neliti.com/media/publications/33412-ID-pengaruh-tingkat-kesulitankeuangan-perusahaan-risiko-litigasi-struktur-kepemili.pdf

Risdiyani, F., \& Kusmuriyanto, K. (2015). Analisis Faktor-Faktor Yang Mempengaruhi Penerapan Konservatisme Akuntansi. Accounting Analysis Journal, 4(3). https://doi.org/10.15294/aaj.v4i3.8305

Rivandi, Muhammad dan Sherly Ariska, "Pengaruh Intensitas Modal, Dividend Payout Ratio dan Financial Distress terhadap Konservatisme Akuntansi" dalam Jurnal Benefita 4(1) Februari 2019

Saputra, Raja Erwin. 2016. "Pengaruh Struktur Kepemilikan Manajerial, Kontrak Utang, 
Tingkat Kesulitan Keuangan Perusahaan, Peluang Pertumbuhan, Risiko Litigasi, dan Leverage Terhadap Konservatisme Akuntansi”. JOM Fekon. Vol. 3, No. 1, Februari 2016 hal: 2207-2221.

Sinambela, M. O. E., \& Almilia, L. S. (2018). Faktor-faktor yang mempengaruhi konservatisme akuntansi. Jurnal Ekonomi dan Bisnis, 21(2), 289-312. https://ejournal.uksw.edu/jeb/article/view/1788/1031

Sugiyarti, L., \& Rina, S. (2020). Pengaruh Insentif Pajak, Financial Distress, Earning Pressure Terhadap Konservatisme Akuntansi. Jurnal Litbang Sukowati: Media Penelitian dan Pengembangan, 4(1), 10-10. https://journal.sragenkab.go.id/index.php/sukowati/article/view/148

Sulastri, S., \& Anna, Y. D. (2018). Pengaruh financial distress dan leverage terhadap konservatisme akuntansi. AKUISISI| Jurnal Akuntansi, 14(1), 58-68.

Susanto, B., \& Ramadhani, T. (2016). Faktor-faktor yang memengaruhi konservatisme (studi pada perusahaan manufaktur yang terdaftar di BEI 2010-2014). Jurnal Bisnis Dan Ekonomi, 23(2). https://www.unisbank.ac.id/ojs/index.php/fe3/article/view/4974

Yuniarti, N. (2020). Pengaruh Financial Distress, Struktur Kepemilikan Manajerial, Risiko Litigasi, dan Leverage Terhadap Konservatisme Akuntansi Pada Perusahaan Manufaktur Sektor Industri Barang Konsumsi yang Terdaftar di Bei Tahun 2015-2018 (Doctoral dissertation, Universitas Pancasakti Tegal). 